\title{
Alteration of inflammatory markers in children and adolescents of multisystem inflammatory syndrome group during novel corona virus infectious disease-2019: A systematic review and meta-analysis
}

\author{
Rupa Biswas ${ }^{1}$, Gargi Das ${ }^{1}$, Kaushambi Basu ${ }^{1},{ }^{* J i n i a}$ Saha ${ }^{1}$
}

Sri Lanka Journal of Child Health, 2021; 50(3): 519-526

\begin{abstract}
Background: To determine the impact of multisystem inflammatory syndrome (MIS) caused by novel coronavirus infectious disease-2019 (nCOVID-19) more investigations are needed related to children and adolescents. Among several inflammatory markers, C-reactive protein (CRP), procalcitonin (PC), ferritin (F) and erythrocyte sedimentation rate (ESR) can be easily done among infected cases to assess the inflammatory status even in asymptomatic cases.
\end{abstract}

Objective: A systematic review and meta-analysis to compare MIS and non-MIS cases in relation to elevation of inflammatory marker in children and adolescents due to nCOVID-19.

Method: Studies providing data on the prevalence of n-COVID-19 in children and adolescents $(<21$ years) were compared between MIS and non-MIS groups. All studies were selected from PubMed and other electronic database and PRISMA guidelines were followed for data abstracting. During screening and quality assessment, each article has been evaluated by two reviewers independently. For each parameter, the rate ratio and $95 \%$ confidence intervals (CIs) were compared between increased and non-increased group through Forest plot model.

Results: The present study indicated elevated range of all studied markers in the children during nCOVID-19 outbreak. The Forest plot indicated low heterogeneity for three studied markers, which can be the important parameter for identifying clinical feature of MIS during nCOVID-19.

\footnotetext{
${ }^{1}$ Calcutta National Medical College and Hospital, India

*Correspondence: jiniasaha007@gmail.com$$
\text { iD }
$$$$
\text { https://orcid.org/ 0000-0003-2710-1082 }
$$

(Received on 31 March 2021: Accepted after revision on 21 May 2021)

The authors declare that there are no conflicts of interest

Personal funding was used for the project.

Open Access Article published under the Creative
}

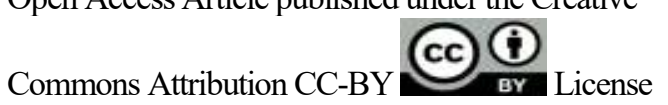

Conclusions: All studied markers (CRP, PC, F and ESR) were elevated in children and adolescents during nCOVID-19 outbreak

DOI: https://dx.doi.org/10.4038/sljch.v50i3.9739

(Key words: nCOVID-19, inflammatory markers, clinical features, children, adolescents)

\section{Introduction}

The outbreak of novel corona virus infectious disease (nCOVID-19) commenced in Wuhan, Hubei Province, China in December 2019 and later, the World Health Organization declared it a pandemic ${ }^{1}$. It was named as severe acute respiratory syndrome coronavirus-2 (SARSCoV-2) after taxonomical identification by the Coronaviridae Study Group (CSG) of the International Committee on Taxonomy of Viruses ${ }^{2}$. This virus spread rapidly in China followed by different parts of the globe and all states in India. It is reported that n-COVID-19 has a higher risk of disease severity and deaths among older people and in persons with underlying comorbidities like hypertension, cardiac disease, chronic lung disease and cancer ${ }^{3-6}$. Many studies indicated that most children did not show manifestations and accounted for 1-2\% of infected cases with minimal casualties ${ }^{7-15}$.

It is well-known that interferon (IFN) is produced by host cells through an antiviral response during viral infection within the body because IFN is the firstline innate immune defence of the body, categorized into IFN- $\alpha$, IFN- $\beta$, etc. ${ }^{16-17}$. A study was conducted on the treatment of upper respiratory tract infections in children using recombinant human IFN- $\alpha 2$ b spray in the mouth and nose as topical therapy, which inhibited viral infection ${ }^{17}$. It is well-established that children have relatively mild clinical manifestations of nCOVID-19 in comparison with adults and a few studies on immunologic features, which may distinguish children with and without "multisystem inflammatory syndrome in children (MIS-C)" are still unclear ${ }^{19-20}$. Moreover, a few studies were elaborated about inflammatory markers in which Creactive protein (CRP) is a common marker and increased due to SARS-CoV-2 $21-26$. 


\section{Objectives}

To assess the alteration of inflammatory markers, especially CRP, in children and adolescents after mild or severe infection by nCOVID-19 through a systemic review and meta-analysis from the diagnostic evidence among hospitalized multisystem inflammatory syndrome (MIS) or nonMIS and asymptomatic patients.

\section{Method \\ Search summary: According to the recent article by Viner RM, et $a l^{27}$ and Institute of Medicine (IOM) standards \& guidelines ${ }^{28}$, the present study was performed by a comprehensive literature search from PubMed, Embase, Cochrane Library and Scopus database, and the last search was done on December 23, 2020. The search keywords for present study were 'nCOVID-19' OR 'Coronavirus' OR 'CoV-2' OR 'nCOVID-19 pandemic' AND 'Children' OR 'Inflammatory markers in children' OR 'Inflammatory markers in paediatrics' OR 'Inflammatory markers in infants' used in varying permutations and combinations, along with extensive cross-referencing. Firstly, we screened all titles and abstracts for relevance to the study and reviewed the full content of the relevant studies. All the relevant studies in the English language were checked and included. The search protocol was followed by the Preferred Reporting Items for Systematic Reviews and Meta-Analyses (PRISMA) as per earlier articles of Viner RM, et $a l^{27}$ and $\mathrm{Wu} \mathrm{Z}$ and Yang $\mathrm{D}^{29}$. Moreover, the researchers selected standards for the development and reporting of clinical practice guidelines from the 'IOM recommendations in Clinical Practice Guidelines We Can Trust ${ }^{28}$. Each clinical practice guideline summary was independently evaluated for compliance by 2 of the reviewers.}

Data extraction: One reviewer (JS) performed the searches and screened for duplicates. Other three reviewers $\mathrm{RB}, \mathrm{GD}$ and $\mathrm{KB}$ independently screened all unique search results for potential abovementioned inclusions used in the systemic review and meta-analysis. In case there were conflicts, discrepancies in the evaluations were resolved through open discussion by two reviewers (JS and RB). Articles passing reviewers' approval were finally considered for inclusion. Finally, data extraction was done (KB) by using a standardized data extraction sheet for extracted data from each study. The data extraction form included (1) author name, (2) year of publication, (3) study area, (4) agegroups for nCOVID-19 diagnosed, (5) inflammatory markers disorders during diagnostic procedure, and (6) number of children/adolescents affected. For Quality Assessment (QA) of selected six studies, the
Joanna Briggs Institute (JBI) Critical Appraisal Checklist for studies reporting prevalence data was used. The final set of articles for inclusion in the review were identified based on the quality of those selected studies. Only the studies of appropriate and good quality were included.

Statistical analysis: The forest plot was used to determine the combined rate ratio (RR) and weight ratio (\%) on specific studies along with corresponding 95\% confidence intervals (CI) to assess the relationship between inflammatory marker and impact of nCOVID-19 among children. This study was carried out by using the metaanalysis software (MetaXL, Version 5.3) developed by Barendregt for obtaining forest plot $^{29-30}$, which determined the elevation of inflammatory markers, especially CRP level, compared between increased and non-increased groups of MIS and non-MIS, or other's groups of asymptomatic children and adolescents by nCOVID- 19 .

In the present study, the contribution made by each reviewer is as follows: JS performed the searches and screened for duplicates; RB, GD, and $\mathrm{KB}$ independently screened all unique search results; conflicts were openly discussed and resolved by JS and $\mathrm{RB}$ for discrepancies in the evaluations; data extraction was done by KB and JS.

\section{Results \\ Selection of studies and characteristics of included studies}

Figure 1 depicts the process of study inclusion. In total, 28 citations were screened, and 24 full articles were retrieved, of which 6 were identified as full text research articles. Of these full text articles, 6 were included in the systemic review and meta-analysis study. The present study carried out the quality appraisal process for these six articles and each article was evaluated by two reviewers (JS and RB) independently and conflicts were resolved after open discussion. After the QA process, only the articles that met quality criteria for inclusion in the review were considered.

\section{Study processing}

The systematic review is based on nCOVID-19 or SARS-CoV-2 infection among children with an alteration of CRP during infection. Six appropriate studies from different countries are compiled only on the patients presenting hyper-inflammatory disorders by increasing CRP, procalcitonin (PC), ferritin (F) and erythrocyte sedimentation rate (ESR) level in MIS or non-MIS groups in nCOVID-19. Table 1 describes the diagnostic features among children after nCOVID-19 symptoms 


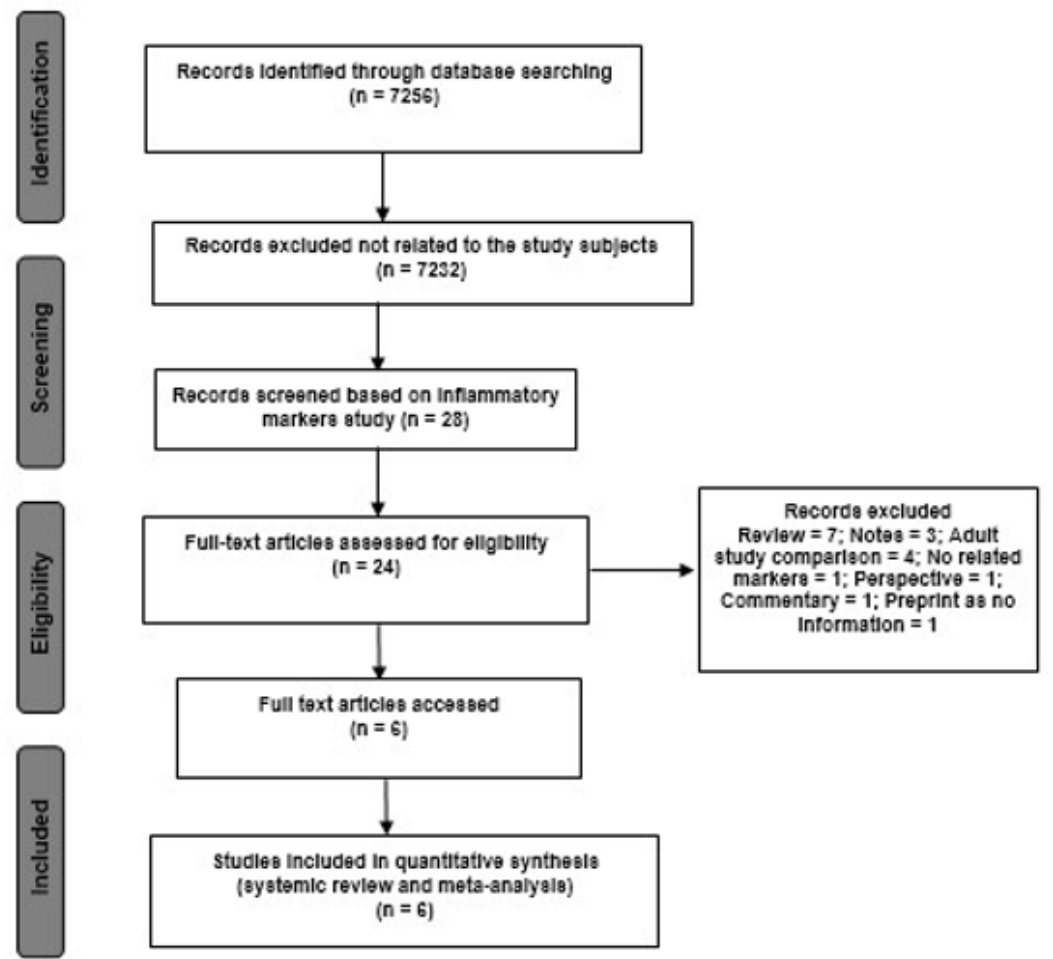

Figure 1: PRISMA flow diagram for included study on inflammatory marker elevation in children during nCOVID-19 outbreak

Table 1: Diagnostic features among children and adolescents due to nCOVID-19

\begin{tabular}{|c|c|c|c|c|c|}
\hline \multirow{2}{*}{$\begin{array}{l}\text { SI. } \\
\text { No. }\end{array}$} & \multirow{2}{*}{$\begin{array}{c}\text { Study } \\
\text { area }\end{array}$} & \multirow[t]{2}{*}{ Study groups } & \multirow[t]{2}{*}{ Study type } & \multirow[t]{2}{*}{ Total cases (n) } & \multirow{2}{*}{$\begin{array}{c}\text { Diagnostic features } \\
\text { PCR }+ \text { \& antibody testing (n) }\end{array}$} \\
\hline & & & & & \\
\hline 1. & USA & Lee PY, et $a l^{21}$ & $\mathrm{R}$ & 28 & 17 \\
\hline 2. & China & Bai $\mathrm{K}$, et $a l^{22}$ & $\mathrm{R}$ & 25 & 25 \\
\hline 3. & USA & Fernandes DM, et $a l^{23}$ & $\mathrm{R}$ and $\mathrm{P}$ & 281 & 281 \\
\hline 4. & Brazil & Prata-Barbosa A, et al ${ }^{4}$ & $\mathrm{P}$ and $\mathrm{O}$ & 79 & 79 \\
\hline 5. & USA & Feldstein LR, et $a l^{25}$ & $P$ & 186 & 131 \\
\hline 6. & USA & Dufort EM, et al ${ }^{26}$ & $\mathrm{P}$ & 99 & 99 \\
\hline
\end{tabular}

$R$ : Retrospective, P: Prospective, O: Observational, PCR: polymerase chain reaction

Lee PY, et $a l^{21}$ evaluated a retrospective study in USA among 28 confirmed cases of SARS-CoV-2 infection in children aged 1 month to 17 years. The study was conducted on MIS in children. Of the 28 children, 17 were found positive through polymerase chain reaction (PCR) test of nasopharyngeal swabs.

Bai $\mathrm{K}$, et $a l^{22}$, in a retrospective study in China found 25 confirmed cases of 2019-nCoV infection after real-time reverse transcription-PCR (RNA-PCR) test in children aged 0.6 to 17 years.

A retrospective and prospective study by Fernandes $\mathrm{DM}$, et $a \mathrm{l}^{23}$ revealed confirmed hospitalized SARSCoV-2 infection in children and youth aged $\leq 22$ years with MIS in USA.
Prata-Barbosa A, et $a l^{24}$ conducted a prospective observational study among 79 children aged 1 month to 19 years infected with nCOVID-19 in Brazil in which 10 had MIS confirmed through realtime reverse transcription-PCR (RT-PCR) test.

Feldstein LR, et $a l^{25}$ conducted a prospective study among 186 children and adolescents of USA aged $<21$ years in which 73 confirmed cases of SARSCoV-2 were based on RT-PCR test and 55 were confirmed after linking with infected COVID persons, but 172 cases were found as MIS children and 14 as non-MIS cases.

Dufort EM, et a ${ }^{26}$ carried out a prospective study in USA among 191 children and adolescents aged $<21$ years in which 99 were confirmed SARS-CoV-2 by RT-PCR test and these cases were with MIS. 
Table 2 describes the demographic profiles viz. age and gender, as well as clinical symptoms, among children and adolescent who underwent hospitalization due to nCOVID-19.
Table 3 describes the alteration of different biomarkers of CRP, PC, F and ESR among children and adolescents after nCOVID-19 outbreak.

Table 2: Demographic profiles and clinical symptoms of children and adolescents during nCOVID-19

\begin{tabular}{|c|c|c|c|c|c|c|}
\hline Studies & Lee et $\mathrm{al}^{2 \mathrm{~T}}$ & Bai et al $^{22}$ & Fernandes et al ${ }^{23}$ & 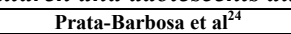 & Feldstein et $\mathrm{al}^{25}$ & Dufort et $\mathrm{al}^{26}$ \\
\hline Total cases $(\mathrm{n})$ & 28 & 25 & 281 & 79 & 186 & 99 \\
\hline Age (years) & $0.1-17.0$ & $0.6-17.0$ & $1.0-17.0$ & IQR $(1.0-10.3)$ & $<1.0-20.0$ & $<20$ \\
\hline Gender (\%) & $\mathrm{M}=57 ; \quad \mathrm{F}=43$ & $\mathrm{M}=56 ; \mathrm{F}=44$ & $\mathrm{M}=61 ; \mathrm{F}=39$ & $\mathrm{M}=54 ; \mathrm{F}=46$ & $\mathrm{M}=62 ; \mathrm{F}=38$ & $\mathrm{M}=54 ; \mathrm{F}=46$ \\
\hline $\begin{array}{l}\text { Symptoms (\%) } \\
\end{array}$ & $\begin{array}{l}\text { Fever } 100 \\
\text { Gastrointestinal } 54 \\
\text { Conjunctivitis } 57 \\
\text { Skin rash } 36\end{array}$ & $\begin{array}{l}\text { Asymptomatic } 32 \\
\text { Fever } 24 \\
\text { Cough } 52 \\
\text { Sore throat } 12 \\
\text { Running nose } 12 \\
\text { Nasal obstruction } 12 \\
\text { Diarrhoea } 4 \\
\text { Weakness } 4\end{array}$ & $\begin{array}{l}\text { Respiratory } 60.8 \\
\text { MIS } 60.9 \\
\text { Others } 59.4\end{array}$ & $\begin{array}{l}\text { Pneumonia or bronchiolitis } 70 \\
\text { MIS + Kawasaki-like disease } 60 \\
\text { Acute cardiac dysfunction } 20 \\
\text { Toxic shock syndrome } 10 \\
\text { MAS } 10\end{array}$ & $\begin{array}{l}\text { Fever } 78 \\
\text { Gastrointestinal } 92 \\
\text { Cardiovascular } 80 \\
\text { Haematologic } 76 \\
\text { Mucocutaneous } 74 \\
\text { Respiratory } 70\end{array}$ & $\begin{array}{l}\text { Fever or chills } 99 \\
\text { Chest pain } 11 \\
\text { Gastrointestinal } 80 \\
\text { Dermatologic } 62 \\
\text { Mucocutaneous } 61 \\
\text { Neurological } 30 \\
\text { Musculoskeletal } 20\end{array}$ \\
\hline
\end{tabular}

MIS: Multisystem inflammatory syndrome; MAS: Macrophage activation syndrome

Table 3: Alteration of inflammatory markers among children and adolescents due to nCOVID-19

\begin{tabular}{|c|c|c|c|c|c|c|}
\hline IM effect & Lee et $\mathrm{al}^{21}$ & Bai et $\mathrm{al}^{22}$ & ${\text { Fernandes et } \mathrm{al}^{23}}^{23}$ & 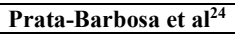 & Feldstein et $\mathrm{al}^{25}$ & Dufort et $\mathrm{al}^{26}$ \\
\hline Parameter & $\mathrm{CRP}>0.5 \mathrm{mg} / \mathrm{dl}$ & $\mathrm{CRP}(\mathrm{mg} / \mathrm{l})$ & $\mathrm{CRP}(\mathrm{mg} / \mathrm{l})$ & $\mathrm{CRP} \geq 3 \mathrm{mg} / \mathrm{dl}$ & $\mathrm{CRP} \geq 3 \mathrm{mg} / \mathrm{dl}$ & $\mathrm{CRP} \geq 3 \mathrm{mg} / \mathrm{dl}$ \\
\hline Increased (n) & 26 & 17 & 212 & 10 & 172 & 98 \\
\hline No or little change (n) & 02 & 08 & 69 & 63 & 14 & 01 \\
\hline Parameter & $\mathrm{PC} \geq 0.1 \mathrm{ng} / \mathrm{mL}$ & - & - & $\mathrm{PC} n g / \mathrm{mL}$ & - & - \\
\hline Increased (n) & 24 & - & - & 02 & - & - \\
\hline No or little change (n) & 01 & - & - & 01 & - & - \\
\hline Parameter & $\mathrm{F}>200 \mathrm{ng} / \mathrm{mL}$ & - & - & $\mathrm{F} \mathrm{ng} / \mathrm{mL}$ & $\mathrm{F}>500 \mathrm{ng} / \mathrm{mL}$ & $\mathrm{F}>300 \mathrm{ng} / \mathrm{mL}$ \\
\hline Increased (n) & 24 & - & - & 07 & 163 & 62 \\
\hline No or little change (n) & 04 & - & - & 17 & 23 & 37 \\
\hline Parameter & $\mathrm{ESR}>30 \mathrm{~mm} / \mathrm{h}$ & - & - & ESR mm/1st h & $\mathrm{ESR} \geq 40 \mathrm{~mm} / \mathrm{h}$ & $\mathrm{ESR} \geq 40 \mathrm{~mm} / \mathrm{h}$ \\
\hline Increased (n) & 15 & - & - & 09 & 117 & 40 \\
\hline No or little change (n) & 09 & - & - & 05 & 69 & 59 \\
\hline
\end{tabular}

Lee PY, et $a l^{21}$ found 26 of 28 children had elevated CRP levels, 24 of 25 cases had increased PC, 24 of 28 cases had increased $\mathrm{F}$ and 15 of 24 cases had elevated ESR (Table 1).

Bai $\mathrm{K}$, et $a l^{22}$ found elevated CRP levels in 17 of 25 cases. According to them, CoV-2 infection increased CRP in mild cases by $1.76 \mathrm{mg} / \mathrm{l}(0.42-2.27 \mathrm{mg} / \mathrm{l})$ and common cases by $2.10 \mathrm{mg} / 1 \quad(0.33-13.18 \mathrm{mg} / \mathrm{l})$ compared to asymptomatic cases by $0.09 \mathrm{mg} / 1(0.03-$ $1.09 \mathrm{mg} / \mathrm{l})$.

Fernandes DM, et $a l^{23}$ studied all MIS cases that SARS-CoV-2 infection increased overall CRP value (212 cases) of $7.8 \mathrm{mg} / \mathrm{l}(1.73-27.2 \mathrm{mg} / \mathrm{l})$ when combined respiratory data of $4.5 \mathrm{mg} / \mathrm{l}$ (1.0$14.5 \mathrm{mg} / \mathrm{l})$, MIS-C data of $25.7 \mathrm{mg} / 1(10-38.1 \mathrm{mg} / \mathrm{l})$ and others of $3.5 \mathrm{mg} / 1$ (0.5-7.9) in comparison with not elevated as normal cases (69 cases).

Prata-Barbosa A, et a ${ }^{24}$ compared the level of CRP, PC, F and ESR between MIS and Non-MIS children after a SARS-CoV-2 infection. Of 79 children, 10 cases of MIS had increasing CRP level of $10 \mathrm{mg} / \mathrm{dl}$ $(9-30 \mathrm{mg} / \mathrm{dl})$ when compared to non-MIS group of $3 \mathrm{mg} / \mathrm{dl}(0.6-18 \mathrm{mg} / \mathrm{dl})$. Interestingly, 63 of 79 children of non-MIS group increased by $\geq 3 \mathrm{mg} / 1$ while all 10 children of MIS group increased by $\geq 10 \mathrm{mg} / \mathrm{l}$ of CRP level. The marker PC (ng/L) was increased in only 2 cases of MIS and did not increase in 1 case among non-MIS. Another marker F (ng/L) was also elevated in 7 cases of MIS and was not elevated in 17 cases of Non-MIS. In the case of ESR (mm/1sth), 9 cases of MIS group found an increasing trend while 5 cases of non-MIS group did not observe any elevation.

Feldstein LR, et $a l^{25}$ analysed the CRP, F and ESR level in MIS children and adolescents in which they categorized MIS age groups as $<5$ years (50 cases), 5-12 years (67 cases), and 13-20 years (39 cases). Their research indicated maximum increase in CRP level (overall $17.8 \mathrm{mg} / \mathrm{dl}$ ) in age groups of $<5$ years (13.6 $\mathrm{mg} / \mathrm{dl}$; IQR [interquartile range] 6.8-19.7 $\mathrm{mg} / \mathrm{dl}), 5-12$ years $(19.3 \mathrm{mg} / \mathrm{dl}$; IQR $15.6-29.2$ $\mathrm{mg} / \mathrm{dl})$ and 13-20 years (23.9 mg/dl IQR 16.3-29.9 $\mathrm{mg} / \mathrm{dl})$, respectively. For overall $\mathrm{F}(>500 \mathrm{ng} / \mathrm{mL})$ marker, an elevated level was observed in 163 cases of MIS group compared to 23 in non-MIS group while the researchers categorized the highest $\mathrm{F}$ level in age groups of $<5$ years $(403.0 \mathrm{ng} / \mathrm{mL}$; IQR 259.8 $732.5 \mathrm{ng} / \mathrm{mL}), 5-12$ years $(679.8 \mathrm{ng} / \mathrm{mL}$; IQR $377.9-$ $1126.9 \mathrm{ng} / \mathrm{mL}$ ) and $13-20$ years (938 ng/mL IQR 449.0-1609.2 ng/mL), respectively. In case of ESR ( $\geq 40 \mathrm{~mm} / \mathrm{h}$ ), an elevated level was observed in 117 cases of MIS group when compared to 69 in nonMIS group and age group-based categorization indicated as $<5$ years $(62 \mathrm{~mm} / \mathrm{h}$; IQR $36.8-88.5$ $\mathrm{mm} / \mathrm{h}), 5-12$ years $(68 \mathrm{~mm} / \mathrm{h}$; IQR $46-100 \mathrm{~mm} / \mathrm{h})$ and $13-20$ years $(66.5 \mathrm{~mm} / \mathrm{h} \mathrm{IQR} 44.2-84.0 \mathrm{~mm} / \mathrm{h})$, respectively. The comparison was done with nonMIS group due to $\mathrm{CoV}-2$ infection.

Dufort EM, et $a l^{26}$ studied children and adolescents of about 99 cases were confirmed by infection of SARS-CoV-2 in which MIS of 99 cases were found. 
The present study was concerned with the CRP level of $\geq 3 \mathrm{mg} / \mathrm{dl}$ in which 98 cases were observed elevated level (median $21.9 \mathrm{mg} / \mathrm{dl}$, IQR 15.0-30.0 $\mathrm{mg} / \mathrm{dl}$ ) and 1 case was reported without increasing value. For F marker $(>300 \mathrm{ng} / \mathrm{mL})$, it was observed an increasing trend of about 62 cases (median 522 $\mathrm{ng} / \mathrm{mL}$, IQR $305-820 \mathrm{ng} / \mathrm{mL}$ ) among MIS group and did not show any change of about 37 cases among
non-MIS group. In the case of ESR ( $\geq 40 \mathrm{~mm} / \mathrm{h}$ ), an elevated level was found of about 40 cases of MIS (median $61.5 \mathrm{~mm} / \mathrm{h}$, IQR $43.0-77.5 \mathrm{~mm} / \mathrm{h}$ ) while did not show elevation of about 59 cases of nonMIS. Figure 2 (A-C) represents the Forest plot in which the rate ratio, $95 \%$ confidence interval $(\mathrm{CI})$ and weight (\%) values in each study was exhibited.
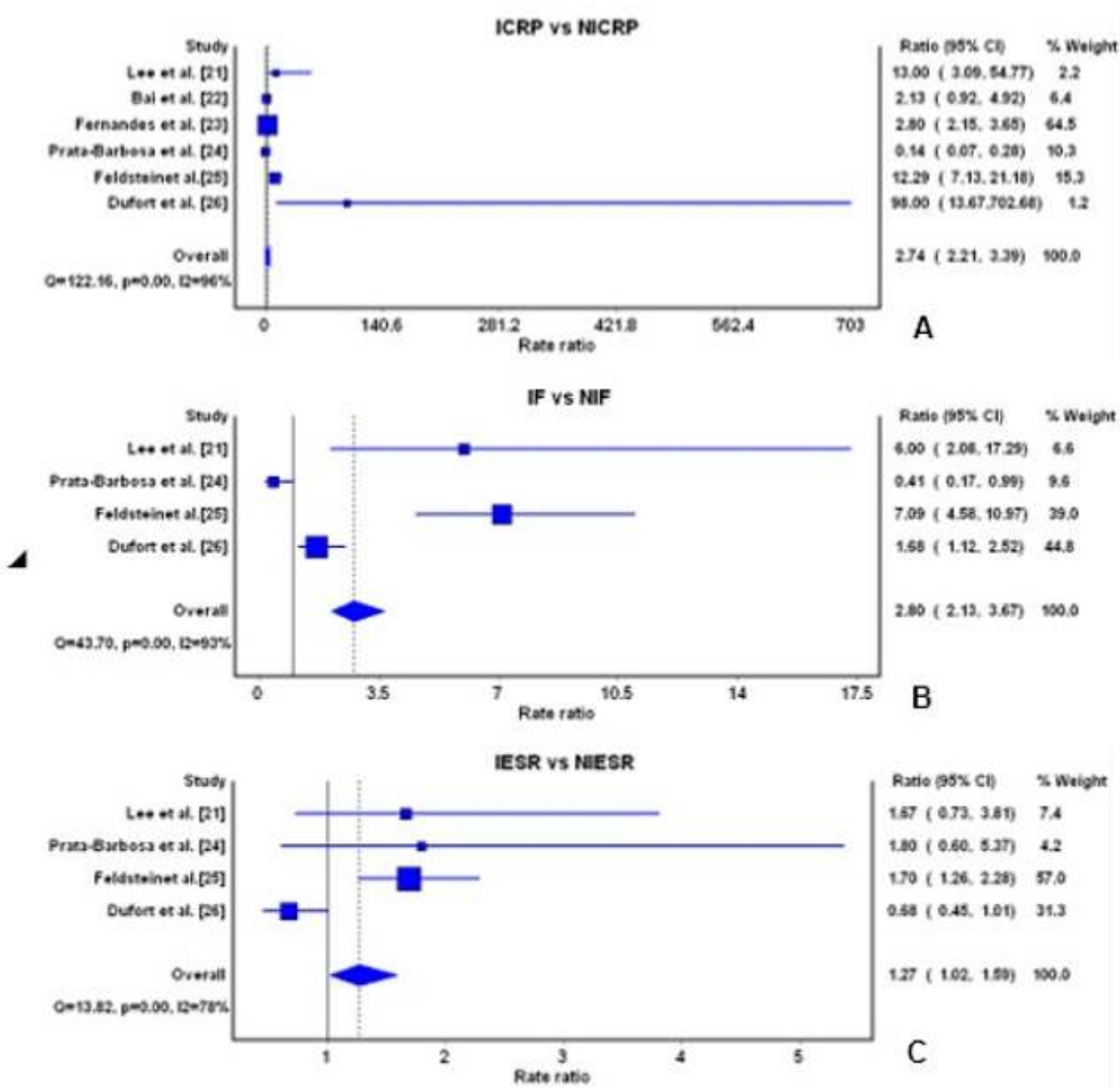

Figure 2: Forest plot representing comparison between increased versus non-increased inflammatory markers (CRP, F, and ESR) during nCOVID-19 outbreak ( $=$ increased; NI $=$ non-increased; $A=$ ICRP vs NICRP; $B=$ IF vs NIF and $C=$ IESR vs NIESR)

Among the six studies for CRP marker, maximum value of weight $(64.5 \%)$ was obtained for Fernandes $\mathrm{DM}$, et $a l^{23}$ due to higher sample size. Moreover, the overall $I^{2}$ value of about $96 \%$ with a Chi square $\mathrm{P}=$ 0.000 and pooled rate ratio with $95 \%$ CI $(2.74 \%$, 2.21-3.39) were obtained. In the case of F marker four studies were evaluated, maximum value of weight $(39.0 \%)$ was obtained for Fernandes DM, et $a l^{23}$ due to higher sample size. Moreover, the overall $I^{2}$ value of about $93 \%$ with a Chi square $\mathrm{P}=0.000$ and pooled rate ratio with $95 \%$ CI $(2.80 \%, 2.13$ 3.67) were obtained. For ESR four studies were evaluated, maximum value of weight $(39.0 \%)$ was obtained for Fernandes DM, et $a l^{23}$ due to higher sample size. Moreover, the overall $I^{2}$ value of about $78 \%$ with a Chi square $\mathrm{P}=0.000$ and pooled rate ratio with $95 \%$ CI (1.27\%, 1.02-1.59) were obtained. In the present study low heterogeneity was observed, which indicated CRP, F and ESR are important diagnostic markers for identifying clinical feature of nCOVID-19.

\section{Discussion}

The present systematic review and meta-analysis observed that CRP is elevated in children and adolescents due to nCOVID-19 among increased (MIS or non-MIS) groups compared to nonincreased groups. However, a positive PCR without 
clinical symptoms was found in children and adolescents of asymptomatic cases as they were MIS or non-MIS group or mild symptoms of nCOVID$19^{21-26}$. The relationship between nCOVID-19 and MIS in children needs more research. The forest plot indicated low heterogeneity, but overall studies showed significant level of CRP, F and ESR elevated groups compared to non-altered groups. Few studies have evaluated the inflammatory biomarkers in which CRP, F and ESR are common ${ }^{21-}$ 26. This review was done to assess whether CRP is increasing or not as well as other biomarkers like $\mathrm{PC}, \mathrm{F}$ and $\mathrm{ESR}^{22}$ but CRP, PC, F and ESR are common in all six studies except the parameter PC and the present study considered CRP, F and ESR to know heterogenicity by using Forest plot. The present study found elevated levels of CRP, $\mathrm{F}$ and ESR in the children during nCOVID-19. In all studies clinical symptoms were more or less same as viral infection. In this study, the samples were small and further research with large numbers of samples is suggested where higher heterogenicity can be achieved. This biomarker can be useful to assess the prevalence of nCOVID-19 in adults followed by comparative study of children versus adult in future studies on systemic review and meta-analysis with higher samples.

\section{Conclusions}

All studied markers (CRP, PC, F and ESR) were elevated in children and adolescents during nCOVID-19 outbreak

\section{References}

1. WHO. Coronavirus disease (COVID2019) Situation Report 2020. Available from: https://www.who.int/ emergencies/diseases/novel-coronavirus2019/events-as-they-happen

2. Gorbalenya AE, Baker SC, Baric RS, et al. The species severe acute respiratory syndrome-related coronavirus: Classifying 2019-nCoV and naming it SARS-CoV-2. Nature Microbiology 2020; 5: 536-44. https://doi.org/10.1038/s41564-020-0695z

PMid: 32123347 PMCid: PMC7095448

3. Alqahtani JS, Oyelade T, Aldhahir AM, et al. Prevalence, severity and mortality associated with COPD and smoking in patients with COVID-19: A rapid systematic review and meta-analysis. PLoS One 2020; 15(5): e 0233147.

https://doi.org/10.1371/journal.pone.0233

147

PMid: 32392262 PMCid: PMC7213702
4. Tobacco use and COVID-19. 11 May 2020 Statement. Geneva: World Health Organization https:/www.who.int/newsroom/detail/11-05-2020-who-statementtobacco-use-and-covid-19 (accessed 14 May 2020)

5. Huang C, Wang Y, Li X, et al. Clinical features of patients infected with 2019 novel coronavirus in Wuhan, China. Lancet 2020; 395(10223): 497-506. https://doi.org/10.1016/S01406736(20)301 83-5

6. Zhou F, Yu T, Du R, et al. Clinical course and risk factors for mortality of adult inpatients with COVID-19 in Wuhan, China: A retrospective cohort study. Lancet 2020; 395(10229): 1054-62. https://doi.org/10.1016/S01406736(20)305 66-3

7. Lu X, Zhang L, Du H, et al. SARS-CoV-2 infection in children. New England Journal of Medicine 2020; 382: 1663-5. https://doi.org/10.1056/NEJMc2005073 PMid: 32187458 PMCid: PMC7121177

8. Dong Y, Mo X, Hu Y, et al. Epidemiology of COVID-19 among children in China. Pediatrics 2020; 145(6): e20200702. https://doi.org/10.1542/peds.2020-0702 PMid: 32179660

9. Cai J, Xu Jin, Lin D, et al. A case series of children with 2019 novel coronavirus infection: clinical and epidemiological features. Clinical Infectious Diseases 2020; 71(6): 1547-51.

https://doi.org/10.1093/cid/ciaa198

PMid: 32112072 PMCid: PMC7108143

10. Xu Y, Li X, Zhu B, et al. Characteristics of paediatric SARS-CoV-2 infection and potential evidence for persistent faecal viral shedding. Nature Medicine 2020; 26: 502-5.

https://doi.org/10.1038/s41591-020-08174

PMid: 32284613 PMCid: PMC7095102

11. Lee PI, Hu YL, Chen PY, et al. Are children less susceptible to COVID19? Journal of Microbiology, Immunology and Infection 2020; 53(3): 371-2. https://doi.org/10.1016/j.jmii.2020.02.011 PMid: 32147409 PMCid: PMC7102573 
12. Fischer, A. Resistance of children to Covid-19. How? Mucosal Immunology 2020; 13: 563-5. https://doi.org/10.1038/s41385-020-03039

PMid: 32467603

13. Salje H, Kiem CT, Lefrancq $\mathrm{N}$, et al. Estimating the burden of SARS-CoV-2 in France. Science 2020; 369(6500): 208-11. https://doi.org/10.1126/science.abc3517 PMid: 32404476 PMCid: PMC7223792

14. Steinmana JB, Lumb FM, Hob PPK, et al. Reduced development of COVID-19 in children reveals molecular checkpoints gating pathogenesis illuminating potential therapeutics. Proceedings of the National Academy of Sciences USA 2020; 117(40): 24620-6.

https://doi.org/10.1073/pnas.2012358117

PMid: 32883878 PMCid: PMC7547272

15. Laxminarayan R, Wahl B, Dudala SR, et al. Epidemiology and transmission dynamics of COVID-19 in two Indian states. Science 2020; 370: 691-7. doi:10.1101/2020.07.14.20153643 https://doi.org/10.1101/2020.07.14.201536 43

16. Merigan TC, Reed SE, Hall TS, et al. Inhibition of respiratory virus infection by locally applied interferon. Lancet 1973; 17: 563-7.

https://doi.org/10.1016/S01406736(73)907 14-9

17. Shen KL, Yang YH. Diagnosis and treatment of 2019 novel coronavirus infection in children: a pressing issue. World Journal of Pediatrics 2020; 16: $219-21$.

https://doi.org/10.1007/s12519-020-

00344-6

PMid: 32026147 PMCid: PMC7091265

18. Shen KL, Shang YX, Zhang H. A multicentre, randomized, controlled clinical study on the efficacy and safety of recombinant human interferon $2 \mathrm{~b}$ spray (pseudomonas) in the treatment of acute upper respiratory tract infection in children. Zhongguo Shiyong Erke Zazhi 2019; 34: 1010-16.

19. Pierce CA, Preston-Hurlburt P, Dai Y, et al. Immune responses to SARS-CoV-2 infection in hospitalized paediatric and adult patients. Science Translational Medicine 2020; 12: eabd5487.

https://doi.org/10.1126/scitranslmed.abd54

87

PMid: 32958614 PMCid: PMC7658796

20. Nakra NA, Blumberg DA, Herrera-Guerra $\mathrm{A}$, et al. Multi-system inflammatory syndrome in children (mis-c) following sars-cov-2 infection: Review of clinical presentation, hypothetical pathogenesis, and proposed management. Children (Basel) 2020; 7(7): 69.

https://doi.org/10.3390/children7070069

PMid: 32630212 PMCid: PMC7401880

21. Lee PY, Day-Lewis M, Henderson, LA, et al. Distinct clinical and immunological features of SARS-CoV-2-induced multisystem inflammatory syndrome in children. Journal of Clinical Investigation 2020; 130(11): 5942-50. https://doi.org/10.1172/JCI141113 PMid: 32701511 PMCid: PMC7598077

22. Bai K, Liu W, Liu C, et al. Clinical analysis of 25 COVID-19 infections in children. Pediatric Infectious Disease Journal 2020; 39(7): e100-e103. https://doi.org/10.1097/INF.00000000000 02740

PMid: 32520888

23. Fernandes DM, Oliveira CR, Guerguis S, et al. The tri-state paediatric COVID-19 research consortium authors, SARS-CoV-2 clinical syndromes and predictors of disease severity in hospitalized children and youth. Journal of Pediatrics 2020. doi: 10.1016/j.jpeds.2020.11.016 https://doi.org/10.1016/j.jpeds.2020.11.01 6

PMid: 33197493 PMCid: PMC7666535

24. Prata-Barbosa A, Lima-Setta F, Santos GR, et al. Paediatric patients with COVID-19 admitted to intensive care units in Brazil: a prospective multicentre study. Journal of Pediatrics (Rio J) 2020; 96: 582-92. https://doi.org/10.1016/j.jped.2020.07.002 PMid: 32781034 PMCid: PMC7402103

25. Feldstein LR, Rose EB, Horwitz SM, et al. Multisystem inflammatory syndrome in U.S. children and adolescents. New England Journal of Medicine 2020; 383(4): 334-46. 
https://doi.org/10.1056/NEJMoa2021680 PMid: 32598831 PMCid: PMC7346765

26. Dufort EM, Koumans EH, Chow EJ, et al. Multisystem inflammatory syndrome in children in New York state. New England Journal of Medicine 2020; 383: 347-58. https://doi.org/10.1056/NEJMoa2021756 PMid: 32598830 PMCid: PMC7346766

27. Viner RM, Mytton OT, Bonell C, et al. Susceptibility to SARS-CoV-2 infection among children and adolescents compared with adults: A systematic review and metaanalysis. JAMA Pediatrics 2020. doi:10.1001/jamapediatrics.2020.4573 https://doi.org/10.1001/jamapediatrics.202 0.4573

PMid: 32975552

28. Wu Z, Yang D. A meta-analysis of the impact of COVID-19 on liver dysfunction. European Journal of Medical Research 2020; 25: 54.

https://doi.org/10.1186/s40001-020-

00454-x

PMid: 33148326 PMCid: PMC7609835

29. Doi SA, Barendregt JJ, Khan S, et al. Advances in the meta-analysis of heterogeneous clinical trials I: The inverse variance heterogeneity model. Contemporary Clinical Trials 2015; 45(Pt A): $130-138$. https://doi.org/10.1016/j.cct.2015.05.009 PMid: 26003435

30. Doi SA, Barendregt JJ, Khan S, et al. Advances in the meta-analysis of heterogeneous clinical trials II: The quality effects model. Contemporary Clinical Trials 2015; 45(Pt A): 123-129. https://doi.org/10.1016/j.cct.2015.05.010 PMid: 26003432 